\title{
Influence of Social Image and Brand Trust on Mobile Phone Brand Equity amongst African Generation Y Students
}

\author{
Christiaan Rudolf Quintus Roets
}

North-West University

Email: christo@croets.co.za

\section{Ayesha Lian Bevan-Dye}

North-West University

Email: ayeshabevandye@gmail.com

Willem Peet Viljoen

North-West University

Email:Peet.Viljoen@nwu.ac.za

\section{Doi:10.5901/mjss.2014.v5n21p75}

\begin{abstract}
In the highly competitive business landscape of the 21st century, intangible assets such as brand equity are deemed as increasingly vital to the long-term success of organisations. Brand loyalty, which is the primary driver of brand equity, germinates from consumers' brand identification, trust in the superiority of the brand and their perceptions of the social esteem that use of the brand signals The mobile phone industry is one of the most dynamic and competitive industries of this century, with new smartphones boasting breakthrough features appearing on the market in rapid succession. As the first generation to be brought up in this era of mobile telephony, the Generation Y cohort (individuals born between 1986 and 2005) represents an important current and future segment for the manufacturers and marketers of mobile devices, including smartphones. The study reported on in this article focused on determining the influence of social image on brand trust and the influence of brand trust on mobile phone brand loyalty and brand equity amongst African Generation $Y$ students in South Africa. A selfadministered questionnaire was distributed to convenience sample of 600 students across the campuses of three public South African higher education institutions situated in the Gauteng province. The captured data was analysed using descriptive statistics, correlation analysis and bivariate regression. The results indicate that social image has a significant positive influence on brand trust, which, in turn, has a significant positive influence on the development of brand loyalty and consequent brand equity.
\end{abstract}

Keywords: mobile phones; brand equity; brand loyalty; brand trust; social image; African Generation Y students

\section{Introduction}

In the highly competitive business landscape of the $21^{\text {st }}$ century, intangible assets such as brand equity (DelgadoBallester \& Munuera-Alemán, 2005) are deemed as increasingly vital to the long-term success of organisations (Gunelius, 2014). In contrast to brand value, which denotes the estimated financial value of a brand in accounting terms, brand equity refers to the wide spread brand preference amongst consumers based on the positive differential effect of a well-known brand name (Kotler, 2003). Brand equity represents a relational market-based asset (Hunt, 1997; Srivastava, Fahey \& Christensen, 2001) that is primarily the product of brand loyalty (Aaker, 1991; Park \& Srinivasan, 1994; Bello \& Holbrook, 1995), which is consumers' consistent preference for one brand over all competing brands within a specific product category (Ferrel \& Hartline, 2008). Brand loyalty and, consequently brand equity, germinates from consumers' brand identification, trust in the superiority of the brand and their perceptions of the social esteem that use of the brand signals (Schiffman, Kanuk \& Wisenblit, 2010). A central concept to brand loyalty is the relationship between the consumer and the brand (Chaudhuri \& Holbrook, 2001). Viewing brand loyalty as a relationship between the consumer and a brand supports the idea that consumers use brands as extensions of their self and as a tool for signalling their self to others (de Chernatony, 2003). Furthermore, trust is a crucial factor in any enduring relationship and, by implication, establishing and maintaining trust in a brand is a necessary precursor to developing brand loyalty and brand equity (Krishnan, 1996). This 
suggests that consumers' perceived social image of a brand, together with their level of trust in that brand are important antecedents of brand loyalty, which, in turn, is the salient determinant of brand equity.

The mobile phone industry is one of the most dynamic and competitive industries of this century, with new smartphones boasting breakthrough features appearing on the market in rapid succession (McCarty, 2011; Mourdoukoutas, 2013; Rowinski, 2014). Mobile phone manufacturers may double or halve their market share on a year on year basis, depending on which technological innovations appeal to consumers at that point in time (Walker \& Mullins, 2011). Given that brand equity facilitates the adoption of new products, mobile phone manufacturers actively seek to build brand loyalty and leverage their resulting brand equity via brand extensions (Schiffman et al., 2010).

As the first generation to be brought up in this era of mobile telephony (Anantatmula \& Shrivastav, 2012), the Generation Y cohort (individuals born between 1986 and 2005) (Markert, 2004) represents an important current and future segment for the manufacturers and marketers of mobile devices, including smartphones. In South Africa, members of the Generation Y cohort accounted for approximately 38 percent of South Africa's population of 52981991 in 2013, with the majority (83\%) being African (Statistics South Africa, 2013). With an estimated 95 percent of the African Generation Y cohort owning a mobile phone (Shevel, 2013), this age and ethnic cohort presents an important segment for mobile phone manufacturers targeting the South African market. Those African Generation $Y$ individuals pursuing a tertiary qualification are of specific relevance to mobile phone marketers in that a tertiary qualification often translates into a higher future earning potential and a higher social standing within a society, which, in combination, increases the likelihood of these individuals being trendsetters (Bevan-Dye, 2013) and influencing the mobile phone brand preferences of their peers. Despite the evident benefits of establishing brand equity for organisations operating in highly dynamic and competitive industries such as the mobile phone industry, there is a dearth of published literature on this topic in the South African context, especially in terms of the country's large and potentially lucrative African Generation Y cohort. Attaining brand equity amongst African Generation $Y$ students should be an important imperative to mobile phone manufacturers seeking to establish a long-term competitive advantage in the South African market.

In light of this, the study reported on in this article focused on determining the influence of social image and brand trust on mobile phone brand loyalty and brand equity amongst African Generation Y students in South Africa.

\section{Mobile Phone Industry}

The first mobile phone, the Motorola DynaTAC 8000X was sold in the United States of America (USA) for US\$3 995 in March 1984. Nicknamed "The Brick", the phone measured $13 \times 1.75 \times 13.5$ inches, weighed 793.80 grams, was only capable of making phone calls and had an estimated battery life of half an hour (Wolpin, 2014). In 2014, 30 years later, the mobile phone has morphed into a high powered, multi-functional smartphone that, over and above being a phone, typically is also a camera, video camera, timepiece, heart monitor, ebook reader, gaming device, music playlist, social networking platform, GPS navigator and email account that provides access to a seemingly unlimited array of online data. In addition to the multitude of features that smartphones offer, they also weigh on average 130 grams and have a stand by battery life of up to 390 hours. As such, mobile phones have evolved into lightweight pocket size devices that offer an all-in-one communication, entertainment, educational, scheduling and navigation solution.

Globally, the mobile phone and smartphone market is expected to grow to US\$150.3 billion in 2014, up from US $\$ 69.8$ billion in 2010 (Markets and Markets, 2011). In 2013, mobile phone sales to end users totalled 1.8 billion units, of which 968 million were smartphones. Whilst Samsung (31\% market share) and Apple (15.6\% market share) were the leading players in the smartphone market, Samsung (24.6\% market share), Nokia (13.9\% market share) and Apple (8.3\% market share) were the dominating forces in the overall mobile phone market in 2013 (Gartner, 2014). In terms of operating systems, the android system dominates, with the iOS system as a close second (IDC, 2013).

Mobile telephony first became available in South Africa in 1994, following Vodacom and MTN being granted licenses to operate the previous year. These two mobile operators were later joined by Cell C in 2001 and Telkom Mobile, which uses the MTN network infrastructure, in 2010.

While Nokia and Blackberry continue to lose market share globally, they remain the market leaders in South Africa. Nokia continued to dominate the South African market in 2013. Blackberry increased its market share from 18 percent in 2012 to 23 percent in 2013. During the same time period, Samsung enjoyed only a marginal increase in market share from 18 percent to 19 percent (World Wide Worx, 2013a). However, even though high-end smartphones such as the Samsung Galaxy range and Apple's iPhone remain too expensive for many, they are an aspirational status symbol (KPMG South Africa, 2013). Whilst the mobile phone penetration rate in South Africa stood at an estimated 128 percent in 2012/2013 (Potgieter, 2013), smartphone penetration in 2013 was estimated to be only 18 percent but is forecasted to increase to 45 percent by 2017 (McLeod, 2013). 


\section{Relationship between Social Image, Brand Trust, Brand Loyalty and Brand Equity}

Brand equity is a strategic imperative for many organisations, particularly those, such as mobile phone manufacturers that operate in highly competitive and dynamic industries (Washburn, Till \& Priluck, 2000; Yoo, Donthu \& Lee, 2000; Kabadayi, Aygün \& Çipli, 2007). The concept of brand equity may be viewed from two broad perspectives - the financialbased perspective and the consumer-based perspective (Lasser, Mittal \& Sharma, 1995; Wood, 2000; Pappu, Quester \& Cooksey, 2005). The financial-based perspective involves defining brand equity as an accounting entry of the estimated total financial worth of the brand; that is, the brand's valuation (Lasser et al., 1995; Wood, 2000; Kotler, 2003; Pappu et al., 2005) as per the accountants' perspective (Wood, 2000). The consumer-based perspective views brand equity as the consumers' perceptions of the value of the brand (Aaker, 1991; Keller, 2003). Typically, marketing academics and practitioners adopt the consumer-based perspective of brand equity, viewing the added value resulting from brand equity as a consumer benefit, as opposed to something that can be quantified (Wood, 2000), and the same approach was adopted in this study.

Kotler (2003:422) defines consumer-based brand equity as the brand power and value created by "the positive differential effect that knowing the brand name has on a customer response to the product or service". Walker and Mullins (2011) indicate that from a marketing perspective, brand equity is the value created by establishing consumer preference for the organisation's brand over competing brands. Belch and Belch (2012), in a similar fashion, highlight that consumerbased brand equity is an intangible asset of added value that is created when consumers form a strong attachment to a brand and view the image of the brand more favourably than that of competing brands based on its differential appeal. Lasser et al. (1995) propose that the concept of consumer-based brand equity may be deconstructed into five main components, namely (1) the global value of (2) consumers' subjective perceptions of a brand (3) relative to competing brands, which (4) positively influences financial performance and that is (5) based on the brand name as well as the physical features of the brand.

Brand equity is a much sought after asset because it offers several advantages that include enabling the organisation to charge a price premium, facilitating acceptance of brand extensions and new products, and providing bargaining leverage with distributors and retailers (Kotler, 2003). In addition, brand equity provides a defence against the marketing efforts of competitors and provides a significant market entry barrier (Delgado-Ballester \& Munuera-Alemán, 2001). Consumers' willingness to pay a price premium for a brand is the best single measure of brand equity and provides a good summary of the overall strength of a brand (Aaker,1996).

The primary antecedent of brand equity is brand loyalty (Aaker, 1991; Park \& Srinivasan, 1994; Bello \& Holbrook, 1995; Atilgan, Aksoy \& Akinci, 2005). Brand equity is the outcome of brand loyalty (Kotler, 2003); that is, brand loyalty is the means and brand equity is the end. Aaker (1996) stresses that brand loyalty is the core dimension of brand equity and that it is of such great importance that other measures of brand equity may be evaluated on the basis of the influence they have on brand loyalty. Whist some authors opine that repeat purchase behaviour is the manifestation of brand loyalty (Dick \& Basu, 1994; Chaudhuri, 1995; Farr \& Hollis, 1997; Fournier and Yao, 1997 \& Kuikka \& Laukkanen, 2012), others view brand loyalty more as an attitude towards a brand, whereby brand loyal consumers have a favourable predisposition towards a particular brand, which helps explain the strong brand-consumer relationship (Delgado-Ballester \& Munuera-Alemán, 2005). Viewed as a relationship-based attitude, brand loyalty refers to the consumers' level of attachment to a brand (Wood, 2000), which may vary in degree from the lowest level of brand recognition, to brand preference, to the highest level of brand insistence, where the consumer is devoted to the brand (Ferrel \& Hartline, 2008).

Trust is a fundamental element in developing and maintaining relationships with consumers, and facilitates brand loyalty (Schiffman et al., 2010). In relationship marketing literature, commitment and trust are viewed as prerequisites of successful long-term relationships, with trust being the antecedent of relationship commitment (Morgan \& Hunt, 1994; Reast, 2005; Harwood \& Garry, 2006). Trust is conceptualised as embodying the characteristics of reliability and integrity (Morgan \& Hunt, 1994). Brand trust is viewed as playing a vital role in building long-term relationships with targeted consumers (Sichtmann, 2007; Phan \& Ghantous, 2013). Consumers' commitment to a brand, which ultimately results in brand loyalty, is rooted in brand trust (Morgan \& Hunt, 1994; Chaudhuri \& Holbrook, 2001; Ball, Coelho \& Machas, 2004).

Brand trust refers to "the willingness of the average consumer to rely on the ability of the brand to perform its stated function" (Chaudhuri \& Holbrook, 2001:82) and may act as a powerful tool for mitigating consumers' perceived risk, whether it be performance-, financial-, time-, social- or psychological-based risk (de Chernatony, 2003). DelgadoBallester, Munuera-Alemán and Yagiie-Guillen (2003) conceptualise brand trust as a two-dimensional construct comprising the attributes of reliability and intentions. The reliability dimension refers to the technical or competence aspect of brand trust in terms of the brand's ability to perform as promised, whilst the intentions dimension refers to the belief that the brand will act in the consumers' best interests and welfare should an unexpected problem with the product 
arise. Viewed as a two-dimensional construct, brand trust then encapsulates the reliability and integrity characteristics of relationship trust, as defined by Morgan and Hunt (1994).

In consumer behaviour, consumption is not limited to gaining physiological and functional benefits but extends to attaining social prestige and self-esteem, and signalling status and self-identity (Elliott \& Wattanasuwan, 1998; Acikalin, Gul \& Develioglu, 2009; Schiffman et al., 2010). An individual's interactions with others within a society result in certain social norms developing that serve to guide social behaviour patterns, including consumption behaviour, and concern for social status has a significant influence on the economic behaviour of people (Acikalin et al., 2009). Brand social image is rooted in the concept of social identity and relates to consumers' use of brands as a method of self-expression, selfenhancement and self-esteem (He, Li \& Harris, 2012). In terms of conspicuous consumption, the social status associated with owning and using a brand becomes a salient factor in brand choice (Atwal \& Williams, 2009). Lassar, Mittal \& Sharma (1995:13) define a brand social image as "the consumer's perception of the esteem in which the consumer's social group holds the brand." Foley, Holzman and Wearing (2007) indicate that in the contemporary world, mobile phones have become a fashion accessory and a source of self-esteem and social prestige.

The social image of the brand refers to ways in which the brand meets consumers' psychological and/or social needs (Keller, 2009). Given that brand trust mitigates perceived risk, including social and psychological risk (de Chernatony, 2003), the brand's social image is likely to influence brand trust, especially in the case of conspicuously consumed products such as mobile phones. He et al (2012) found that a brand's social image influences brand loyalty via the significant direct effect it has on brand trust.

\section{Generation Y Cohort}

The concept of generational cohorts is important to market segmentation in that the circumstances and environmental forces shared by a particular age group whilst growing up influence those individuals' behaviour, including their consumer behaviour and set them apart from other generations (Twenge \& Cambell, 2008). The identified Generational cohorts range from the seniors right down to the youth, labelled as Generation Y, which, according to Markert (2004), and Eastman and Liu (2012), includes individuals born between 1986 and 2005. Members of this generation were the first to grow up in the Internet-facilitated digitally connected world, where online social networking, instant messaging, 24/7 access to information and mobile telephony are typically considered the norm. Global media, an ever increasing number of advertising platforms and reality television shows depicting the lives of the uber-wealthy has also seen them exposed during their formative years to a greater number of brands as well as the social esteem afforded by those brands. In combination, these factors have resulted in a generation of technologically astute individuals who are more informed and connected than any previous generation (Autry \& Berge, 2011).

In marketing terms, the youth market has always been important because as people mature and acquire their own disposable income so they act on the brand awareness and preference established during their formative years (Gillingham, 2014). Successfully targeting the Generation $Y$ cohort necessitates understanding the way in which they consume media and engage with brands (Masote, 2012).

Studies in South Africa suggest that the mobile phone is central to the Generation Y individual's life (Naidoo, 2009; Generation Next, 2011; Generation Next, 2014; Pillay, 2014), ranked ahead of clothes, music, money, happiness, friends and love (Generation Next, 2014). The popularity of the Nokia and Blackberry brand amongst university and college Generation Y students seems to be waning in favour of the Apple iPhone and the Samsung mobile phone (World Wide Worx, 2013b). This sentiment appears to be echoed amongst the wider South African Generation Y adult Generation Y cohort, with Apple and Samsung being ranked the two top 'coolest' mobile phone brands (Generation Next, 2014). Evidence suggests that these individuals have shifted their mobile phone spending from phone calls to text messaging, Internet surfing and downloading (World Wide Worx, 2013a). The WhatsApp instant messaging app and Facebook social networking site still dominate amongst both the student portion (World Wide Worx, 2013b) and wider adult South African Generation Y cohort (Generation Next, 2014), with 2014 social networking trends including necknominations and the cancer awareness no-makeup selfies. Marketers who are able to initiate such online trending activities are more likely to create a relationship between their brand and members of this cohort. Given that the largest South African age group on Facebook is the 18 to 34 year olds (Social Bakers, 2014), Facebook-based brand communities may be a viable method of targeting this segment, especially given that Barton, Fromm and Egan (2012) indicate that this generation tends to prefer brand Facebook pages. 


\section{Methodology}

\subsection{Target population, sampling frame and sampling method}

The target population of this study was defined as African males and females aged between 18 and 24 years, enrolled at a South African registered public higher education institution (HEI) in 2013. The sampling frame comprised a list of those HEls located in the Gauteng province as the majority of the country's HEls are located in this province. A non-probability sampling method, namely judgment sampling, was used to narrow the sampling frame to the campuses of three HEls one from a traditional university, one from a university of technology and one from a comprehensive university.

A non-probability convenience sample of 600 students across the three campuses (200 per campus) was taken. Lecturers at each of the three campuses were contacted and asked if they would allow their students to complete the questionnaire, either during lectures or just after. Fieldworkers distributed the questionnaire to the students of those lecturers from whom permission had been attained. Participation was strictly on a voluntary basis and assurance of the confidentiality of the information supplied as well as the name of the $\mathrm{HEl}$ at which the participant was registered was provided.

\subsection{Research instrument}

In order to collect the required data, a self-administered questionnaire was utilised. The self-administered questionnaire included two scales from previously published studies. The scale developed and validated by Delgado-Ballester et al. (2003) was used to measure African Generation Y students' brand trust (that is, brand reliability and brand intentions), and brand loyalty concerning their currently owned mobile phone brand. Following the example of Delgado-Ballester and Munuera-Alemán (2005), brand equity was measured using the scale developed by Yoo and Donthu (2001). The scale comprised five constructs, namely brand reliability (five items), brand intentions (four items), brand loyalty (four items) and brand equity (four items). In addition, the five-item scale developed and validated by Lassar et al. (1995) was used to measure African Generation Y students' perception of their mobile phone's social image. A six-point Likert scale, ranging from disagree completely (1) to agree completely (6) was used to anchor all of the scaled responses. The questionnaire also included a section designed to obtain the demographic information of the participants.

The questionnaire was pilot tested on a sample of 50 students at a HEl campus that did not form part of the sampling frame. The Cronbach alphas calculated for each of the constructs in the pilot study ranged 0.78 and 0.94 , thereby signalling acceptable internal consistency reliability (Pallant, 2010).

\section{Results}

Of the 600 questionnaires distributed, 460 complete questionnaires were returned, which equates to a 77 percent response rate for the main study. In terms of the three HEI campuses, 41 percent of the participants were registered at the traditional university, 32 percent at the comprehensive university and 27 percent at the university of the technology. Male participants accounted for 40 percent of the sample, whereas female participants represented 60 percent of the sample. While each of the seven age categories of the defined target population were represented, the majority of the participants (71\%) were between 19 and 21 years of age. A description of the sample is given in Table 1.

Table 1. Sample description

\begin{tabular}{cccccc}
\hline Gender & Percent (\%) & Age & Percent (\%) & Institution type & Percent (\%) \\
\hline Male & 40 & 18 & 8 & Traditional university & 41 \\
Female & 60 & 19 & 25 & Comprehensive university & 32 \\
& & 20 & 24 & University of technology & 27 \\
& 21 & 22 & & \\
& 22 & 12 & & \\
\hline
\end{tabular}

The Cronbach alpha values computed in the main study were all above the recommended level of 0.70 and ranged from 0.73 for brand equity, 0.71 for brand loyalty, 0.76 for brand intentions, 0.85 for brand reliability and 0.75 for social image, . 
In terms of the descriptive statistics, means above 4.00 were computed on each of the constructs. The highest mean was recorded for social image and brand reliability, suggesting that African Generation $Y$ students rate the social image and brand reliability of their mobile phone brand high.

Table 2. Descriptive statistics

\begin{tabular}{lcc}
\hline Construct & Mean & Standard deviation \\
\hline Social Image & 4.52 & 0.99 \\
Brand reliability & 4.49 & 1.10 \\
Brand intentions & 4.14 & 1.01 \\
Brand loyalty & 4.03 & 1.20 \\
Brand equity & 4.21 & 1.14 \\
\hline
\end{tabular}

Correlation analysis, using Pearson's Product-Moment coefficient, was conducted in order to determine whether there were relationships between African Generation $Y$ students' attitudes towards the social image, brand reliability, brand intentions, brand loyalty and brand equity of their mobile phone brand. Table 3 reports on the findings of the correlation coefficients computed.

Table 3. Relationship between social image, brand reliability, brand intentions, brand loyalty and brand equity

\begin{tabular}{lccccc}
\hline & Social image & Brand reliability & Brand intentions & Brand loyalty & Brand equity \\
\hline Social image & 1 & $0.730^{*}$ & $0.608^{*}$ & $0.678^{*}$ & $0.683^{*}$ \\
Brand reliability & & 1 & $0.699^{*}$ & $0.713^{*}$ & $0.742^{*}$ \\
Brand intentions & & & 1 & $0.601^{*}$ & $0.639^{*}$ \\
Brand loyalty & & & & 1 & $0.694^{*}$ \\
Brand equity & & & & 1 \\
\hline *Significant at the 0.05 level (2-tailed) & & & \\
\hline
\end{tabular}

As is evident from Table 3, there are statistically significant positive relationships between African Generation Y students' attitudes towards the social image, brand reliability, brand intentions, brand loyalty and brand equity of their mobile phone brand. The strongest relationships occurred between the brand trust dimension of reliability and brand equity $(r=0.742$, $p<0.05)$, social image and brand reliability $(r=0.730, p<0.05)$, and brand reliability and brand loyalty $(r=0.713, p<0.05)$. This infers that the higher the perceived social image of the mobile phone brand, the greater the perceived reliability of the brand, which, in turn, increases the brand loyalty towards the brand and consequent brand equity.

In order to ascertain the influence of social image on brand trust, and the influence of the reliability and intensions dimensions of brand trust on brand loyalty and brand equity, regression analysis was carried out. The results of the regression analysis are provided in Table 4.

Table 4: Regression analysis

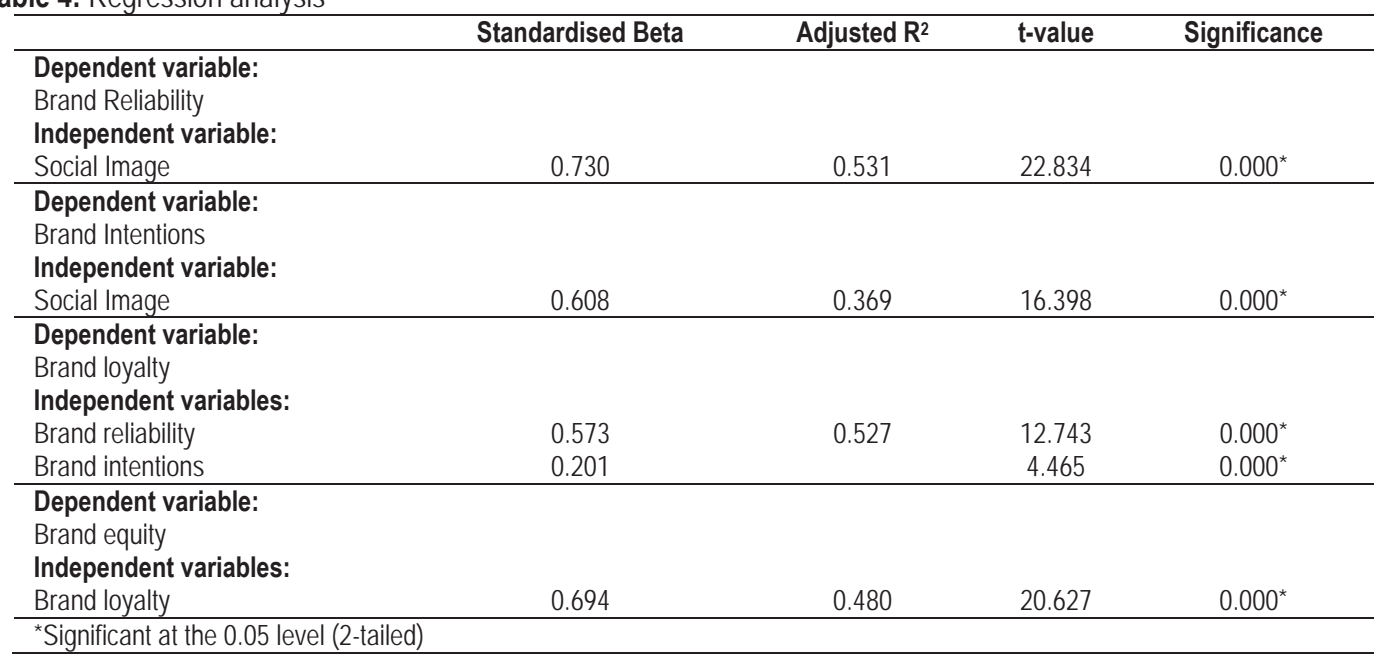


Table 4 reveals that social image has a significant positive influence on the reliability $(\beta=0.730, p=0.000<0.05)$ and intentions ( $\beta=0.608, p=0.000<0.05)$ dimensions of African Generation $Y$ students' perceived trust in their mobile phone brand. Social image accounts for 53 percent of the variance in brand reliability and 37 percent of the variance in brand intensions, which infers that, in comparison to brand intentions, brand reliability is more dependent on social image. The brand trust accounts for 53 percent of the variance in brand loyalty and while both of its dimensions of reliability $(\beta=0.573$, $p=0.000<0.05)$ and intensions $(\beta=0.201, p=0.000<0.05)$ have a significant positive influence on mobile phone brand loyalty, brand reliability makes the strongest unique contribution to explaining brand loyalty. Brand loyalty, in turn, has a significant positive influence on brand equity $(\beta=0.694, p=0.000<0.05)$ and explains 48 percent of the variance in African Generation $Y$ students' brand equity, thereby confirming the hypothesised relationship between the two as per the literature.

\section{Discussion}

The study reported on in this article sought to determine the influence of social image on brand trust and the influence of brand trust on mobile phone brand loyalty and brand equity amongst African Generation Y students in South Africa. The findings of the study indicate that brand social image is positively associated with brand trust, which is positively associated with brand loyalty which, in turn, has a positive relationship with brand equity.

In accordance with the literature, brand loyalty was found to be a significant positive predictor of brand equity. Furthermore, the two dimensions of brand trust - reliability and intentions were both found to be essential to developing brand loyalty and, consequently, brand equity. Similar to the findings of Delgado-Ballester and Munuera-Alemán (2005), of the two, brand reliability was found to be the stronger predictor of brand loyalty towards mobile phone brands amongst African Generation Y students.

African Generation Y students' perceived mobile phone brand reliability was found to be more reliant on social image than mobile phone brand intensions were, suggesting that brand reliability is strongly related to the status implications of owning a particular brand amongst members of this cohort. In this study, the brand intensions dimension was concerned with consumers' trust in the mobile phone manufacturer satisfactorily addressing any issue should a problem arise rather than on their willingness and ability to deliver consumer satisfaction in the manner promised, which was the reliability dimension of brand trust. As such, it is not surprising that the brand's social image would have a greater influence on brand reliability as opposed to brand intensions. The importance of social image in predicting brand reliability has important implications to mobile phone marketers. The whole point of using products to signal status to others is that the product is easily identifiable to other people. Therefore, mobile phone brands need to carry an easily recognisable logo or have a distinguishable design that sets them apart from other brands. Attention should also be given to developing accessories such as mobile phone covers and wearable technology that serve to further differentiate a brand from its competitors. Furthermore, advertising themes in mass media need to strive to bring the brand's personality and emotional values to life, whether it be through the imagery or the music of the copy. Individuals often form impressions about a brand based on the type of people the observe using the brand (de Chernatony, 2003), and even though marketers cannot control this, they can certainly use carefully selected celebrities to publically endorse their brand, thereby reinforcing what the brand stands for. In addition, besides using traditional media platforms to reach lack Generation $Y$ individuals, use should also be made of new digital platforms, especially online social networking sites. Establishing a Facebook page, initiating or, at least playing a role in the latest online trending activity and having a following on twitter are fundamental to reaching this cohort.

\section{Limitations and Future Research}

As with any study, this study has certain limitations that need to be considered when interpreting the results. First, a cross-sectional research design was followed, which only provides a snapshot in time. Given the rapid rate of change in the mobile phone industry, a longitudinal design may provide a more in-depth understanding of the influence of social image and brand trust on the development of brand loyalty and consequent brand equity. Secondly, the study made use of non-probability sampling, which limits the generalizability of the results to the target population. Thirdly, the sample included participants registered at campuses situated in only one province of South Africa, and conducting a study at campuses across the provinces may yield different results. 


\section{Conclusion}

Social image and brand trust are important determinants of level of brand loyalty African students have towards mobile phone brands in the South African market. As such, both elements are essential to developing brand equity for mobile phone manufacturers targeting this lucrative market segment.

\section{References}

Aaker, D. A. (1991). Managing brand equity: capitalizing on the value of a brand name. New York, NY: The Free Press.

Aaker, D. A. (1996). Measuring brand equity across products and markets. California Management Review, 38(3), 102-120.

Acikalin, S., Gul, E. \& Develioglu, K. (2009). Conspicuous consumption patterns of Turkish youth: case of cellular phones. Young Consumers: Insights and Ideas for Responsible Marketers, 10(3), 199-209.

Anantatmula, V. S. \& Shrivastav, B. (2012). Evolution of project teams for Generation Y workforce. International Journal of Managing Projects in Business, 5(1), 9-26.

Atilgan, E., Aksoy, Ş. \& Akinci, S. (2005). Determinants of the brand equity: a verification approach in the beverage industry in Turkey. Marketing Intelligence \& Planning, 23(3), 237-248.

Atwal, G. \& Williams, A. (2009). Luxury brand marketing - the experience is everything. Journal of Brand Management, 16(1), 338-346.

Autry, A. J. \& Berge, Z. (2011). Digital natives and digital immigrants: getting to know each other. Industrial and Commercial Training, $43(7), 460-466$.

Ball, D., Coelho, P. S. \& Machas, A. (2004). The role of communication and trust in explaining customer loyalty: an extension to the ECSI model. European Journal of Marketing, 38(9/10), 1272-1293.

Barton, C., Fromm, J. \& Egan, C. (2012). The millennial consumer: debunking stereotypes. [Online] Available: http://www.bcgperspectives.com (November 20, 2013).

Belch, G.E. \& Belch, M.A. (2012). Advertising and promotion: an integrated marketing communication perspective. New York, NY: McGraw-Hill Irwin.

Bello, D. C. \& Holbrook, M. B. (1995). Does an absence of brand equity generalize across product classes? Journal of Business Research, 34(2), 125-131.

Bevan-Dye, A. L. (2013). Black Generation Y students' attitudes towards Web advertising value. Mediterranean Journal of Social Sciences, 4(2):155-164.

Chaudhuri, A. (1995). Brand equity or double jeopardy? Journal of Product \& Brand Management, 4(1), 26-32.

Chaudhuri, A. \& Holbrook, M. B. (2001). The chain of effects from brand trust and brand affect to brand performance: the role of brand loyalty. Journal of marketing, 65(2), 81-93.

De Chernatony, L. (2003). Brand building. In M.J. Baker (Eds.), The Marketing Book (pp. 373-394). Butterworth-Heineman: Oxford.

Delgado-Ballester, E., \& Munuera-Alemán, J. L. (2001). Brand trust in the context of consumer loyalty. European Journal of Marketing, 35(11/12), 1238-1258.

Delgado-Ballester, E., \& Munuera-Alemán, J. L. (2005). Does brand trust matter to brand equity? Journal of Product \& Brand Management, 14(3), 187-196.

Delgado-Ballester, E., Munuera-Alemán, J. L. \& Yagiie-Guillent, M. J. (2003). Development and validation of brand trust scale. International Journal of Market Research, 45(1), 35-53.

Dick, A. S. \& Basu, K. (1994). Customer loyalty: toward an integrated conceptual framework. Journal of the Academy of Marketing Science, 22, 99-113

Eastman, J. K. \& Liu, J. (2012). The impact of generational cohorts on status consumption: an exploratory look at generational cohort and demographics on status consumption. Journal of Consumer Marketing, 29(2), 93-102.

Elliott, R. \& Wattanasuwan, K. (1998). Brands as symbolic resources for the construction of identity. International Journal of Advertising, 17(1), 131-144.

Farr, A. \& Hollis, N. (1997). What do you want your brand to be when it groups up: big and strong? [Online] Available: http://www.warc.com/fulltext/JAR/9078.htm (August 28, 2013).

Ferrel, O. C. \& Hartline, M. D. (2008). Marketing strategy. (4th ed.). Mason, OH: Thomson South-Western.

Foley, C., Holzman, C. \& Wearing, S. (2007). Moving beyond conspicuous leisure consumption: adolescent women, mobile phones and public space. Leisure Studies, 26(2), 179-192.

Fournier, S. \& Yao, J. (1997). Reviving brand loyalty: a reconceptualization within the framework of consumer-brand relationships. International Journal of Research Marketing, 14(5), 451-472.

Gartner. (2014). Gartner says annual smartphone sales surpassed sales of feature phones for the first time in 2013. [Online] Available: http://www.gartner.com/newsroom/id/2665715 (June 6, 2014).

Generation Next. (2011, May 29). Youth brand survey. Sunday Times, p. 11.

Generation Next. (2014, June 1). Youth brand survey. Sunday Times, p. 16.

Gillingham, A. (2014, June 1). Lessons to learn. Sunday Times, p. 2.

Gunelius, S. (2014). Brand equity basics - part 1: what is brand equity? [Online] Available: https://aytm.com/blog/research- 
junction/brand-equity-basics-1/ (June 23, 2014).

Harwood, T. G. \& Garry, T. (2006). Relationship marketing: why bother? Handbook of Business Strategy, 7(1), 107-111.

He, H., Li, Y. \& Harris, L. (2012). Social identity and brand loyalty. Journal of Business Research, 65(1), 648-657.

Hunt, S. D. (1997). Competing through relationships: grounding relationships marketing in resource-advantage theory. Journal of Marketing Management, 13, 431-445.

IDC (International Data Corporation). (2013). Worldwide mobile phone market forecast to grow 7.3\% in 2013 driven by 1 billion smartphone shipments, according to IDC. [Online] Available: http://www.idc.com/getdoc.jsp?containerld=prUS24302813 (June 1, 2014).

Kabadayi, E. T., Aygün, İ. \& Çipli, Ç. (2007). The effects of marketing mix strategies on brand equity: mobile phone sector. Journal of Global Strategic Management, 2, 74-81.

Keller, K. L. (2003). Strategic brand management: building, measuring and managing brand equity. (2nd ed.). Englewood Cliffs, NJ: Prentice-Hall.

Keller, K. L. (2009). Building strong brands in a modern marketing communications environment. Journal of Marketing Communications, 15(2-3), 139-155.

Kotler, P. (2003). Marketing management. (11th ed.). Upper Saddle River, N.J.: Prentice Hall.

KPMG South Africa. (2013). Looking to the future of telecommunications in South Africa. [Online] Available: http://www.sablog.kpmg.co.za/2013/08/looking-to-the-future-of-the-telecommunications-in-south-africa/ (April 27, 2014).

Krishnan, H. S. (1996). Characteristics of memory associations: a consumer-based brand equity perspective. International Journal of Research in Marketing, 13(4), 389-405.

Kuikka, A. \& Laukkanen, T. (2012). Brand loyalty and the role of hedonic value. Journal of Product \& Brand Management, 21(7), 529537.

Lassar, W., Mittal, B., \& Sharma, A. (1995). Measuring customer-based brand equity. Journal of Consumer Marketing, 12(4), 11-19.

Markert, J. (2004). Demographics of age: generational and cohort confusion. Journal of current issues and research in advertising, 26(2):11-25.

Markets and Markets. (2011). Global smartphone market worth US $\$ 150.3$ billion by 2014. [Online] Available: http://www.marketsandmarkets.com/Market-Reports/smartphone-market-219.html (April 12, 2014).

Masote, M. (2012, May 20). How to tap the teen market. Sunday Times, p. 6.

McCarty, B. (2011). The history of the smartphone. [Online] Available: http://thenextweb.com/mobile/2011/12/06/the-history-of-thesmartphonel (June 22, 2014).

McLeod, D. (2013). Shocking truth of mobile in Africa. [Online] Available: http://www.techcentral.co.za/shocking-truth-of-mobile-inafrica/44982/ (March 18, 2014).

Morgan, R. M., \& Hunt, S. D. (1994). The commitment-trust theory of relationship marketing. Journal of Marketing, 58(3), 20-38.

Mourdoukoutas, P. (2013). The game is changing in the smartphone market. [Online] Available: http://www.forbes.com/sites /panosmourdoukoutas/2013/01/10/the-game-is-changing-in-the-smartphone-market/ (June 22, 2014).

Naidoo, S. (2009, June 14). Cellphones 'centre of teen universe'. Sunday Times, p. 6.

Pallant, J. (2010). SPSS survival manual: a step by step guide to data analysis using SPSS for Windows. (4th ed.). New York: McGrawHill.

Pappu, R., Quester, P.G. \& Cooksey, R.W. (2005). Consumer-based brand equity: improving the measurement - the empirical evidence. Journal of Product \& Brand Management, 14(3), 143-154.

Park, C. S. \& Srinivasan, V. (1994). A survey-based method for measuring and understanding brand equity and its extendibility. Journal of Marketing Research, 31(2), 271-288.

Phan, K. N., \& Ghantous, N. (2013). Managing brand associations to drive customers' trust and loyalty in Vietnamese banking. International Journal of Bank Marketing, 31(6), 456-480.

Pillay, T. (2014, June 15). Cellphones for kids not always so smart. Sunday Times, p. 6.

Potgieter, F. (2013). The mass market engages with mobile. [Online] Available: http://m.themediaonline.co.za/2013/09/the-mass-marketengages-with-mobile/?wpmp_switcher=mobile (March 29, 2014).

Reast, J. D. (2005). Brand trust and brand extension acceptance: the relationship. Journal of Products and Brand Management, 4(1), 413.

Rowinski, D. (2014). Why 2014 is the year of the cheap smartphone. [Online] Available: http://readwrite.com/2014/03/24/cheapsmartphone-2014\#awesm= 0158hRQ0IKT7Gz (June 23, 2014).

Schiffman, L. G., Kanuk, L. L. \& Wisenblit, J. (2010). Consumer behavior. (10th ed.). Upper Saddle River, NJ: Pearson Prentice Hall.

Shevel, A, (2013). Black diamonds outshine whites. [Online] Available: http://www.bdlive.co.za/national/2013/04/28/black-diamondsoutshine-whites (May 18, 2013)

Sichtmann, C. (2007). An analysis of antecedents and consequences of trust in a corporate brand. European Journal of Marketing, 41(9/10), 999-1015.

Social Bakers. (2014). South Africa Facebook statistics. [Online] Available: http://www.socialbakers.com/facebook-statistics/south-africa (June 2, 2014).

Srivastava, R. K., Fahey, L. \& Christensen, H. K. (2001). The resource-based view and marketing: the role of market-based assets in gaining competitive advantage. Journal of Management, 27(6), 777-802.

Statistics South Africa. (2013). Mid-year population estimates 2013. [Online] Available: http://beta2.statssa.gov.za/publications/ 
P0302/P03022013.pdf(November 24, 2013).

Twenge, J. M. \& Campbell, S. M. (2008). Generational differences in psychological traits and their impact on the workplace. Journal of Managerial Psychology, 23(8), 862-877.

Walker, O. C. \& Mullins, J. W. (2011). Marketing strategy: a decision-focused approach. (7th ed.). New York, NY: McGraw-Hill Irwin.

Washburn, J. H., Till, B. D. \& Priluck, R. (2000). Co-branding: brand equity and trial effects. Journal of Consumer Marketing, 17(7), 591604.

Wolpin, S. (2014). The first cellphone went on sale 30 years ago for $\$ 4,000$. [Online] Available: http://mashable.com/2014/03/13/firstcellphone-on-sale/ (June 6, 2014).

Wood, L. (2000). Brands and brand equity: definition and management. Management Decision, 38(9), 662-669.

World Wide Worx. (2013a). Welcome to the data economy. [Online] Available: http://www.worldwideworx.com/mobileconsumer2014/ (May 17, 2014).

World Wide Worx. (2013b). Social media: addiction and boon to students. [Online] Available: http://www.worldwideworx.com/high-techstudents/ (January 19, 2014).

Yoo, B. \& Donthu, N. (2001). Developing and validating a multidimensional consumer-based brand equity scale. Journal of Business Research, 52(1), 1-14.

Yoo, B., Donthu, N. \& Lee, S. (2000). An examination of selected marketing mix elements and brand equity. Journal of the Academy of Marketing Science, 28(2), 195-211. 